\title{
THE ALEUTIAN CACKLING GOOSE IN ARIZONA
}

DAVID VANDER PLUYM, 2841 McCulloch Blvd. N \#1, Lake Havasu City, Arizona, 86403; dvanpluym@gmail.com

ABSTRACT: There is little published information about the occurrence of the Aleutian Cackling Goose (Branta hutchinsii leucopareia) in Arizona. Formerly listed as endangered by the U.S. Fish and Wildlife Service, this subspecies has rebounded, leading to an increase in numbers occurring outside its core range, including Arizona. Since the first in 1975, at least 24 well-founded records for Arizona have accumulated, one supported by a specimen, two by band recoveries, and 20 by diagnostic photographs. Since 2013 the Aleutian Cackling Goose has occurred in Arizona annually between November and February. It is most frequent along the Colorado River, but records extend as far east as Willcox, Cochise County.

The taxonomy of the "white-cheeked" geese is complex and debated. Currently, most treatments list 11 or 12 taxa in this group, and Banks et al. (2004) split them into two species: the Cackling Goose (Branta hutchinsii) and the Canada Goose (B. canadensis). Taxonomists generally recognize four extant subspecies of the Cackling Goose: hutchinsii, taverneri, minima, and leucopareia (Aleutian Cackling Goose). The now extinct population formerly breeding in the Commander and Kuril islands in Russia and wintering south to Japan has been considered a separate subspecies, asiatica (Banks et al. 2004), or a western population of leucopareia (e.g., Baldassarre 2014, Reeber 2015). Birds discovered breeding on the Semidi Islands in 1979 and wintering in coastal Oregon are phenotypically intermediate between other populations of leucopareia and taverneri (Hatch and Hatch 1983) and do differ genetically from other populations of leucopareia, but they likely represent distinct populations of leucopareia rather than a valid separate taxon (Pierson et al. 2000, Mlodinow et al. 2008). For a fuller discussion of this taxonomy see Banks (2007, 2009), Mlodinow et al. (2008), and Reeber (2015.) Taxonomic flux and difficulties with identification have contributed to confusion on the status of the various subspecies of the Cackling Goose in Arizona, including the Aleutian Cackling Goose.

Historically, the Aleutian Cackling Goose bred on islands south of the Alaska Peninsula (as far east as near Kodiak Island), throughout the Aleutian-Commander arc, and in the Kuril Islands south of Kamchatka in Russia (Byrd and Woolington 1983). The population breeding in Alaska probably wintered in Oregon and California, while the Asian population wintered in Japan (Byrd and Springer 1976). During the late 1800s and especially in the first half of the 1900s, the Aleutian Cackling Goose underwent a steep population decline largely due to the arctic foxes (Vulpes lagopus) introduced to the Aleutian Islands for the fur trade (Murie 1959, Bailey 1993). This goose was thought to possibly be extinct before being rediscovered in 1962 on Buldir Island in the western Aleutians (Jones 1963). Mini et al. (2011) provided an overview of the history of the recovery achieved through the removal of the introduced foxes, captive breeding and translocation of birds, and habitat protection and management in areas of migration and wintering. In response, the Aleutian Cackling Goose population, which probably comprised fewer than 1000 birds in 1967 when it was listed as endangered 
(Byrd 1998), recovered to population in excess of 30,000 birds by 2001, when it was removed from the endangered species list, providing one of the success stories of the Endangered Species Act (Faust and Bailey 1999). By 2010 , the population was estimated at over 100,000 birds, wintering at an increasing number of locations in the Central Valley of California and along the coast of northern California and Oregon (Mini et al. 2011).

\section{HISTORY IN THE ARIZONA LITERATURE AND STATUS IN NEIGHBORING REGIONS}

Likely because of difficulties in identification and the severe population decline, the Aleutian Cackling Goose has a checkered history in the Arizona literature. It has long been thought to occur in Arizona (Monson and Phillips 1981), and Brown (1985) stated that it is occasionally encountered, but specific published Arizona records are lacking. Byrd and Springer (1976) mentioned a band recovery from Mohave County in 1975 (see records below). After the split of $B$. hutchinsii from $B$. canadensis, the Arizona Bird Committee $(\mathrm{ABC})$ placed the former on its review list in an attempt to understand its status here (Rosenberg et al. 2007). It was on the review list from 2005 to 2009, and some reports prior to the split were reviewed (Rosenberg et al. 2007, 2011). Though several reports during that period were not submitted or reviewed, the $\mathrm{ABC}$ accepted 13 records (Rosenberg et al. 2017) before concluding that the species occurred in Arizona regularly enough to forgo further review (Rosenberg et al. 2017). Though the committee was hesitant to identify individuals to subspecies, and considered leucopareia as "unconfirmed" in the state, at least one accepted record was identified as such by the observers (Table 1). Mlodinow et al. (2008) also referenced a single a band recovery in "western Arizona" (there are two band recoveries for Arizona, see below; this likely referred to the first). Using an unconventional taxonomy (see Banks 2007, 2009, 2011), Hanson (2007) and Anderson (2010) reported a specimen collected in 1994 that is referable to this subspecies.

Two published records exist for neighboring Sonora, Mexico, though one of those-in Phillips et al. (1964) — was not included by Russell and Monson (1998), who mentioned only a band recovered from three geese taken in December 1975 from the Colorado River delta. In adjacent southern California from the time of population decline to 1980 there were no reports from coastal areas (Garrett and Dunn 1981), though leucopareia had occurred in the Salton Sink (Patten et al. 2003). During the 1980s and 1990s, the Aleutian Cackling Goose was generally considered casual in coastal southern California (e.g., Lehman 2018). Since the population increase, this taxon is now the most regularly occurring Cackling Goose subspecies in southern California, including in the deserts and the Salton Sink, and is typically considered rare but regular (Lehman 2018). The status along the Baja California peninsula is similar to that in southern California, the subspecies becoming rarer farther south, though it has summered in Baja California Sur (Erickson et al. 2013). Southern Nevada had early records in November 1951 (Alcorn 1988) and November 1979 (Nevada Bird Record Committee data: record 2008-080) but the next not until 2009. Though few Cackling 
Table 1 Photos and sightings of the Aleutian Cackling Goose in Arizona ${ }^{a}$

\begin{tabular}{|c|c|c|c|c|}
\hline Date range & $\begin{array}{l}\text { Number of } \\
\text { individuals }\end{array}$ & Location & County & Source $e^{b}$ \\
\hline 19-21 Nov 2007 & 1 & Flagstaff & Coconino & $\begin{array}{l}\text { S3283791, Rosenberg et al. } \\
\text { (2011) }\end{array}$ \\
\hline 11 Nov 2011 & 2 & Havasu NWR & Mohave & $\begin{array}{c}\text { S9202509, AZFO } \\
\text { seasonal report }{ }^{c}\end{array}$ \\
\hline 3 Feb 2013 & 1 & Mohave Valley & Mohave & $\begin{array}{c}\text { AZFO seasonal report, } \\
\text { S12841563 }\end{array}$ \\
\hline 4 Dec 2013 & 2 & Lake Havasu City & Mohave & $\begin{array}{l}\text { AZFO photo page and seasonal } \\
\text { report, S15872881, Figure } 2\end{array}$ \\
\hline 17 Jan 2014 & 1 & Cibola NWR & La Paz & $\begin{array}{l}\text { AZFO seasonal report, } \\
\text { S16437760 }\end{array}$ \\
\hline 17 Jan-4 Feb 2014 & 1 & Glendale & Maricopa & eBird, AZFO seasonal report \\
\hline 5 Dec 2014 & 1 & Cibola NWR & La Paz & $\begin{array}{c}\text { S20848906, AZFO seasonal } \\
\text { report }\end{array}$ \\
\hline 2 February 2015 & 1 & Cibola NWR & La Paz & $\begin{array}{l}\text { AZFO photo page and seasonal } \\
\text { report, eBird, Figure } 3\end{array}$ \\
\hline $\begin{array}{l}4 \text { Dec 2015- } \\
12 \text { Feb } 2016\end{array}$ & 2 & Avondale & Maricopa & eBird, AZFO seasonal report \\
\hline 8-19 Dec 2015 & 1 & Sun Lakes & Maricopa & S26216421, S26190964 \\
\hline $\begin{array}{l}18 \text { Dec 2015- } \\
9 \text { Jan } 2016\end{array}$ & $6^{d}$ & Cibola NWR & La Paz & $\begin{array}{l}\text { AZFO photo page and } \\
\text { seasonal report, eBird }\end{array}$ \\
\hline 30 Dec 2016 & 2 & Avondale & Maricopa & S33297069 \\
\hline 3 Jan 2017 & 1 & Payson & Gila & S33416067 \\
\hline 29 Jan 2017 & 1 & Lake Montezuma & Yavapai & S34042040, S34206289 \\
\hline 6 Feb 2017 & 1 & Mohave Valley & Mohave & S35199682 \\
\hline 16 Feb 2017 & 1 & Cibola NWR & La Paz & S34480322 \\
\hline 3-8 Nov 2017 & 11 & Tucson & Pima & AZFO photo page, eBird \\
\hline 6 Nov 2017 & 3 & Page & Coconino & S40350097 \\
\hline 8 Nov 2017 & $5^{e}$ & Page & Coconino & S40379355 \\
\hline & 1 & Willcox & Cochise & S40424837 \\
\hline 26 Jan 2018 & 2 & Scottsdale & Maricopa & S42258544 \\
\hline
\end{tabular}

${ }^{a}$ All records supported by photos unless noted otherwise.

bSources beginning with S followed by eight numbers are web pages available through https://ebird.org; for example, S3283791 is https://ebird.org/view/checklist/S3283791. There may be more information in other checklists but these checklists represent the main documentation on ebird. Where eBird is cited the record is supported multiple checklists with documentation. AZFO seasonal reports are available at www. azfo.net/reports.html. AZFO photo pages are available at www.azfo.net/gallery/1main/photos_tax.html.

cSight record only.

${ }^{d}$ Total on the first date; by the second date only a single individual was seen.

eIt is unknown if this flock was new or additional birds joined the 6 November 2017 flock.

Geese are identified to subspecies in Nevada and the current status of the Aleutian Cackling Goose is not certain, it is believed to be a rare but regular winter visitor (J. R. Tinsman, in litt., 2019), being more regular in northwest Nevada (M. Myers, in litt., 2019). As in southern Nevada, most Cackling Geese reported from southern Utah are not identified to subspecies and/or lack photos, and the Aleutian is unconfirmed there (R. Fridell, in litt., 2019). 


\section{METHODS}

I searched for records of the Aleutian Cackling Goose from Arizona through the spring of 2018. I searched the data of the Bird Banding Laboratory (last checked 16 Oct 2018), www.idigbio.org (accessed 21 Feb 2019), www.portal.vertnet.org (accessed 21 Feb 2019), and www.inaturalist.org (accessed 21 Feb 2019). ABC reports, North American Birds reports, and Arizona Field Ornithologists (AZFO) seasonal reports often did not specify the subspecies of a Cackling Goose, but where possible I examined individual records. Other than the band recoveries and one archived specimen, all other records in the state have been of birds photographed or they included descriptions identifying the bird(s) as Aleutian Cackling Goose when submitted to www.ebird.org (last checked 16 Oct 2018) or the AZFO's photodocumentation page (www.azfo.org; last checked 16 Oct 2018). I searched all known relevant primary and secondary literature on the identification and taxonomy of Branta and on Arizona birds.

Identification followed criteria put forth in Mlodinow et al. (2008). Identification to subspecies is often more difficult from photos than it is in the field (Mlodinow et al. 2008), and because of confusion in birders' subspecies identifications, I took a conservative approach and acknowledge that some records may have been overlooked.

\section{FIRST ARIZONA RECORDS}

The first record of the Aleutian Cackling Goose from Arizona was of a bird banded on Buldir Island, Alaska, 14 August 1975, and recovered at "Topock," Mohave County, Arizona, 12 December 1975 (Bird Banding Laboratory data, Byrd and Springer 1976). This occurrence preceded the start of the population's recovery, though there were records from the 1970s in adjacent states. It is also of interest that it was in the same year and month as the three cited above from the Colorado River delta. It is not clear why this record was not included in previous accounts of "white-cheeked" geese in Arizona, but the Sonora record and lack of a specimen might have led to confusion.

The second record is based on the only Arizona specimen (disposition of the birds responsible for other band recoveries is not known), mentioned above, a female shot at Cibola National Wildlife Refuge, La Paz County, 18 December 1994 (Field Museum 457844, Figure 1). This specimen was earlier in a private collection. At the time, the Aleutian Cackling Goose was still rare in southern California, with only four records for the Salton Sink (Patten et al. 2003).

An individual originally banded near Manteca, California (one of the subspecies' main wintering locations), on 18 December 2003 was recovered in the Mohave Valley, Mohave County, on 17 November 2005. This was during a time when numbers in southern California were increasing. All subsequent reports for Arizona have been of individuals photographed or well described.

\section{CURRENT STATUS}

Arizona's first sight/photographic records came in 2007 and 2011, and since 2013 the Aleutian Cackling Goose has been recorded every year 


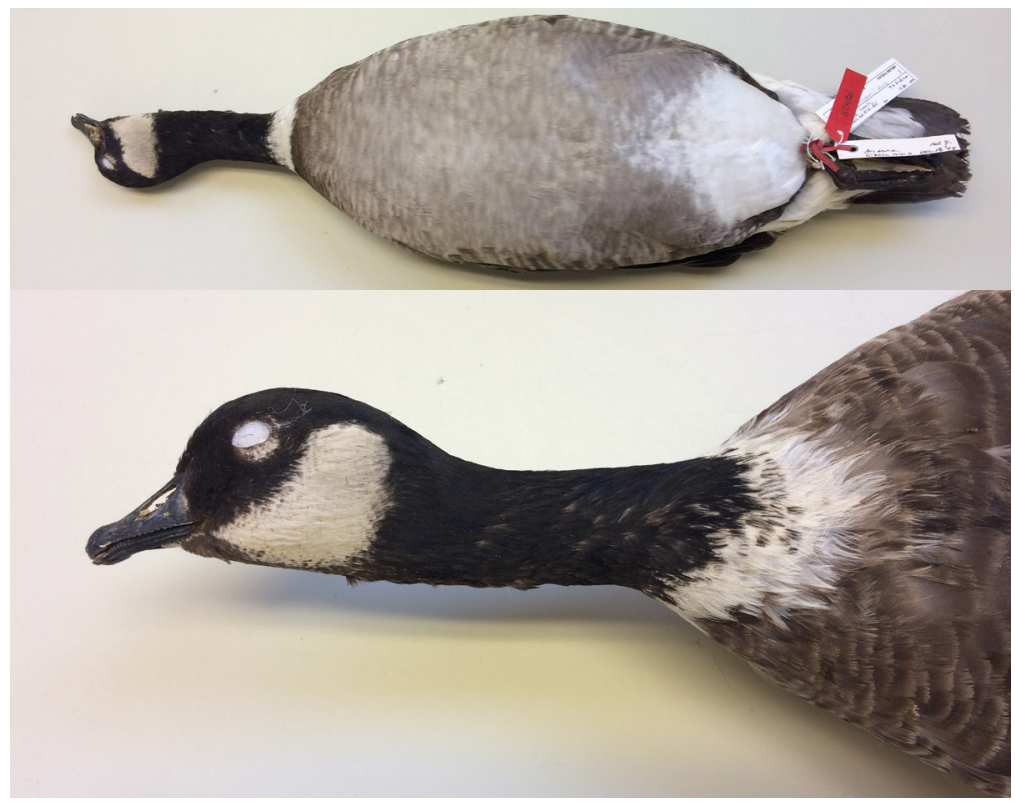

Figure 1. Aleutian Cackling Goose collected at Cibola National Wildlife Refuge, La Paz County, Arizona, 18 December 1994 (Field Museum 457844). Note the wide white neck ring subtended by a darker collar, the darker gray breast contrasting with the belly, and the black complete gular stripe, characteristics of an adult of Branta hutchinsii leucopareia.

Photos by Josh Engels

(Table 1). The ABC may review subspecies, typically those it considers field identifiable and with fewer than 30 records. At the ABC's 2018 meeting, I led a discussion of adding the Aleutian Cackling Goose to the review list. While the committee agreed the subspecies has occurred in the state, the $\mathrm{ABC}$ chose not to add it to the review list, citing that there were already 24 Arizona records and that because its numbers continue to increase in adjacent southern California, a 30-record threshold would likely be reached shortly. Though the majority of records are from western Arizona, with the lower Colorado River valley accounting for half of them (six each in La Paz and Mohave counties), records are scattered east to southeast Arizona. Flocks of wintering geese around Phoenix account for five records, a fifth of the total. Though the Aleutian Cackling Goose is unconfirmed in southern Utah, there is at least one record from nearby Page, Coconino County. Most reports in Arizona are of single individuals or small groups; the high count is of a flock of 11 in Tucson, 3-8 November 2017.

The Aleutian Cackling Goose has been recorded in Arizona from 3 November through 16 February. Records are split almost evenly between late fall migrants and birds likely wintering, with two records from the Mohave Valley, Mohave County, on 3 February 2013 and 6 February 2017 


\section{THE ALEUTIAN CACKLING GOOSE IN ARIZONA}

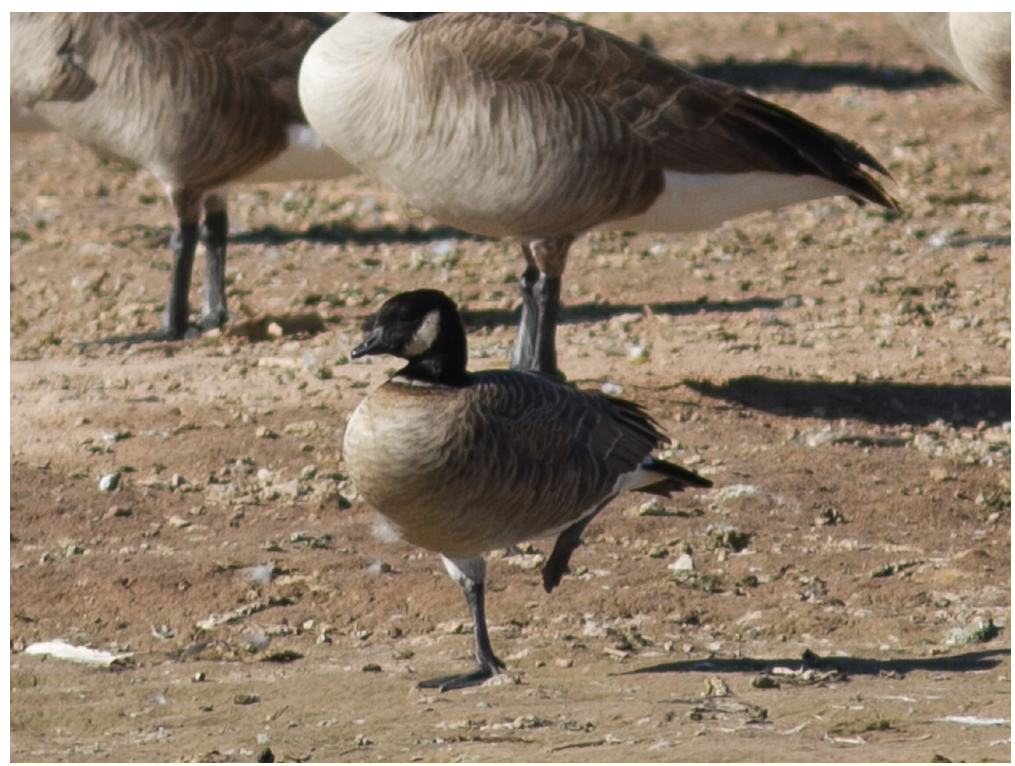

Figure 2. Aleutian Cackling Goose at Cibola National Wildlife Refuge, La Paz County, Arizona, 2 February 2015. Note the small size, dark brown chest with a contrasting dark ring between it and the white collar, as well as the head and bill shape. The apparent width of the white neck ring varies not only from individual to individual but also by how the bird is holding its neck.

Photo by David Vander Pluym

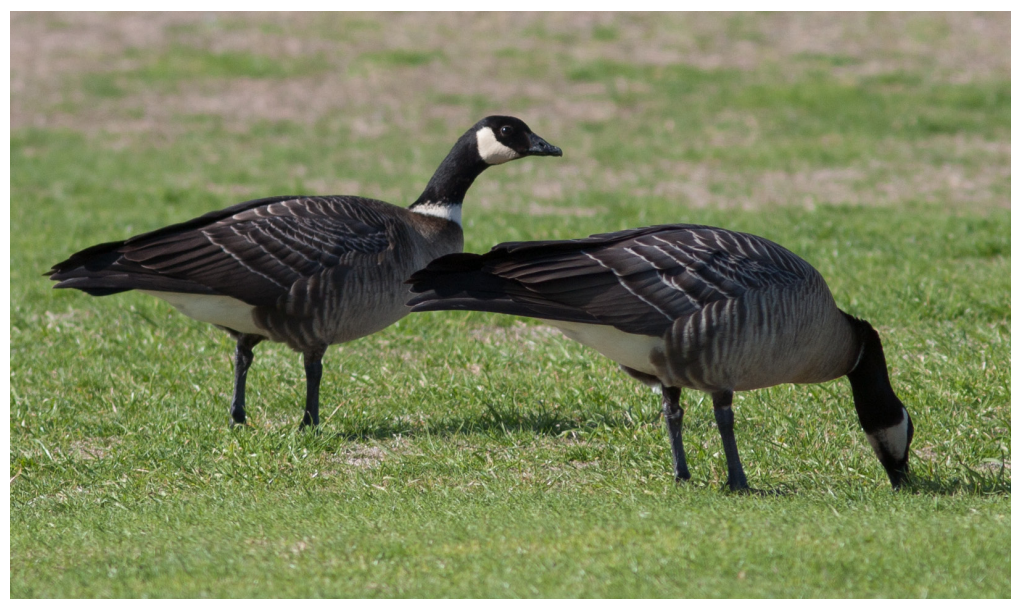

Figure 3. Aleutian Cackling Geese, the third photographed in Arizona, along the Colorado River at Lake Havasu City, Mohave County, 4 December 2013. 
representing early spring migrants. December has the most records, a mix of likely migrants and wintering birds. There is no indication that any individual has yet attempted to summer in Arizona.

Of the four subspecies of the Cackling Goose, only minima was known from Arizona historically (Monson and Phillips 1981). This subspecies has apparently declined here and now occurs less than annually. Currently, most reports, particularly in the eastern half of the state, are of nominate hutchinsii. While taverneri has been claimed in Arizona (AZFO photo pages at www.azfo.net/gallery/1main/photos_tax.html; www.ebird.org), its status is uncertain. Currently it appears that leucopareia is the second-most regular subspecies of the Cackling Goose in Arizona.

As the population of the Aleutian Cackling Goose continues to increase, it may show up anywhere in Arizona, either in a pure flock or with Canada Geese. Though much of Arizona is in the Sonoran Desert, with extremely high temperatures, it is still likely that an individual will summer in the state, as the subspecies has summered at similar latitudes and in similar climates, as in southern Nevada and Baja California Sur.

\section{ACKNOWLEDGMENTS}

Thanks to Josh Engels (Field Museum) for providing photos of the specimen. Thanks to Danny Bystrak (Bird Banding Lab) for providing information on the two band recoveries in Arizona. Jeanne R. Tinsman and Martin Myers provided information on the status of the Aleutian Cackling Goose in Nevada, as did Rick Fridell for Utah. Lauren Harter provided many helpful comments on an early draft, on which Bruce Deuel and Troy Corman provided additional helpful comments. Thanks to Vernon Byrd and Daniel Gibson for their careful reviews.

\section{LITERATURE CITED}

Alcorn, J. R. 1988. The Birds of Nevada. Fairview West, Fallon, NV.

Anderson, B. W. 2010. Evolution and Taxonomy of White-cheeked Geese. Avvar Books, Blythe.

Bailey, E. P. 1993. Introduction of foxes to Alaskan islands-history, effects on avifauna, and eradication. U.S. Fish and Wildlife Service Res. Publ. 193.

Baldassarre, G. 2014. Ducks, Geese, and Swans of North America, vol. 1. Johns Hopkins Univ. Press, Baltimore.

Banks, R. C. 2007. Book Review: The White-cheeked Geese: Branta canadensis, B. maxima, B. "lawrensis," B. hutchinsii, B. leucopareia, and B. minima. Taxonomy, Ecophysiographic Relationships, Biogeography, and Evolutionary Considerations. Vol. 1. Eastern Taxa. Wilson J. Ornithol. 119:514-516.

Banks, R. C. 2009. Book Review: The White-cheeked Geese: Branta canadensis, B. maxima, B. "lawrensis," B. hutchinsii, B. leucopareia, and B. minima. Taxonomy, Ecophysiographic Relationships, Biogeography, and Evolutionary Considerations. Vol. 2. Western Taxa. Wilson J. Ornithol. 121:658-660.

Banks, R. C. 2011. Book Review: Evolution and Taxonomy of White-cheeked Geese. Wilson J. Ornithol. 123:650-654.

Banks, R. C., Cicero, C., Dunn, J. L, Kratter, A. W., Rasmussen, P. C., Remsen, J. V. Jr., Rising, J. D., and Stotz, D. F. 2004. Forty-fifth supplement to the American Ornithologists' Union's Checklist of North American Birds. Auk 121:985-995; doi 10.2307/4090341.

Brown, D. E. 1985. Arizona Wetlands and Waterfowl. Univ. Arizona Press, Tucson.

Byrd, G. V. 1998. Current breeding status of the Aleutian Canada Goose, a recovering endangered species, in Biology and Management of Canada Geese (D. H. 


\section{THE ALEUTIAN CACKLING GOOSE IN ARIZONA}

Rusch, M. D. Samuel, D. D. Humburg, and B. D. Sullivan, eds.), pp. 21-28. 1998 International Canada Goose Symposium, Milwaukee, WI.

Byrd, G. V., and Springer, P. F. 1976. Recovery program for the endangered Aleutian Canada Goose. Cal-Neva Wildl. Trans. 1976:65-73.

Byrd, G. V., and Woolington, D. W. 1983. Ecology of Aleutian Canada Geese at Buldir Island, Alaska. U.S. Fish and Wildlife Service Spec. Sci. Rep. Wildlife 253:1-18.

Erickson, R. A., Carmona, R., Ruiz-Campos, G., Iliff, M. J., and Billings, M. 2013. Annotated checklist of the birds of Baja California and Baja California Sur, second edition. N. Am. Birds 66:582-613.

Faust, N., and Bailey E. 1999. An Aleutian Canada Goose success story. Birding $31: 271-274$.

Garrett, K., and Dunn, J. 1981. Birds of Southern California: Status and Distribution. Los Angeles Audubon Soc., Los Angeles.

Hanson, H. C. 2007. The White-cheeked Geese: Branta canadensis, B. maxima, B. "lawrensis," B. hutchinsii, B. leucopareia, and B. minima. Taxonomy, Ecophysiographic Relationships, Biogeography, and Evolutionary Considerations. Vol. 2. Western Taxa. Avvar Books, Blythe.

Hatch, S. A., and Hatch, M. A. 1983. An isolated population of small Canada Geese on Kaliktagik Island, Alaska. Wildfowl 34:130-136.

Jones, R. D. Jr. 1963. Buldir Island, site of a remnant breeding population of Aleutian Canada Geese. Wildfowl Trust Annu. Rep. 14:80-83.

Lehman, P. E. 2018. The Birds of Santa Barbara County, California, rev. ed; www. sbcobirding.com/lehmanbosbc.html.

Mini, A. E., Bachman, D. C., Cocke, J., Griggs, K. M., Spragens, K. A., and Black, J. M. 2011. Recovery of the Aleutian Cackling Goose Branta hutchinsii leucopareia: 10-year review and future prospects. Wildfowl 61:3-29.

Mlodinow, S. G., Springer, P. F., Deuel, B., Semo, L. S., Leukering, T., Schonewald T. D., Tweit, W., and Barry, J. H. 2008. Distribution and identification of Cackling Goose (Branta hutchinsii) subspecies. N. Am. Birds 62:344-360.

Monson, G., and Phillips, A. R. 1981. Annotated Checklist of the Birds of Arizona, 2nd ed. Univ. Ariz. Press, Tucson.

Murie, O. J. 1959. Fauna of the Aleutian Islands and Alaska Peninsula. N. Am. Fauna 61; doi 10.5962/bhl.title.86971.

Patten, M. A., McCaskie, G., and Unitt, P. 2003. Birds of the Salton Sea. Univ. Calif. Press, Berkeley.

Phillips, A., Marshall, J., and Monson G. 1964. The Birds of Arizona. Univ. Arizona Press, Tucson.

Pierson, B. J., Pearce, J. M., Talbot, S. L., Shields, G. F. and Scribner, K. T. 2000. Molecular genetic status of Aleutian Canada Geese from Buldir and the Semidi Islands, Alaska. Condor 102:172-180; doi 10.1650/0010-5422(2000)102[0172:MGSOAC]2.0.CO;2.

Reeber, S. 2015. Waterfowl of North America, Europe, and Asia: An Identification Guide. Princeton Univ. Press, Princeton, NJ.

Rosenberg, G. H., Radamaker, K., and Stevenson, M. 2007. Arizona Bird Committee Report, 2000-2004 records. W. Birds 38:74-101.

Rosenberg, G. H., Radamaker, K., and Stevenson, M. 2011. Arizona Bird Committee Report, 2005-2009 records. W. Birds 42:198-232.

Rosenberg, G. H., Radamaker, K., and Vander Pluym, D. 2017. Arizona Bird Committee Report, 2010-2014 records. W. Birds 48:74-112; doi 10.21199/ WB48.2.1.

Russell, S. M., and Monson, G. 1998. The Birds of Sonora. Univ. Arizona Press, Tucson. 